DOI: $10.17516 / 1997-1370-0673$

УДК 349.6

\title{
Strategic Regulatory Instruments in Environmental Law of Russia
}

\author{
Irina O. Krasnova* and Valery N. Vlasenko \\ Russian State University of Justice \\ Moscow, Russian Federation
}

Received 23.12.2019, received in revised form 31.08.2020, accepted 05.10.2020

\begin{abstract}
At the moment, there are new types of legal acts emerging in environmental law of Russia. Despite the vague legal nature of the strategic documents, they are gaining relevance in regulating environmental relationship though the regulation by strategic documents has become an uncontrolled and unpredictable process. This article reviews strategic and political documents addressing protection of the environment, environmental security and nature use. It points out the necessity to find their place within the system of environment-related legal acts to build a clear hierarchy in the system, to raise the efficiency of laws and to create a functional enforcement mechanism. The authors suggest two options: to adopt a separate legislative act on the national environmental policy or to introduce a separate chapter into the Federal Law "On Environmental Protection", or alternatively, to carry out codification of the adopted strategic instruments.
\end{abstract}

Keywords: strategic documents, environmental law, use of natural resources, Ecological Doctrine, environmental security, national policy of ecological development, pollution fees, economic security.

Research area: law.

Citation: Krasnova, I.O., Vlasenko, V.N. (2020). Strategic regulatory instruments in environmental law of Russia. J. Sib. Fed. Univ. Humanit. Soc. Sci., 13(10), 1671-1678. DOI: 10.17516/1997-1370-0673.

(C) Siberian Federal University. All rights reserved

* Corresponding author E-mail address: kafzem@rsuj.ru

ORCID: 0000-0003-4074-404X (Krasnova); 0000-0001-7479-2774 (Vlasenko) 
The current system of environmental law of Russia witnesses the emergence of new types of legal acts that add to the traditional set of evidently mandatory statutes, governmental regulations and new instruments of administrative rules being the strategic documents that outline the environmental policies of the country.

Enactment of the documents has raised an issue of determining their legal force, their place in the hierarchy of statutes and other legal acts, and options for their implementation.

To a great extent, the socio-economic development of the society depends on the availability of natural resources forming a material basis for economic growth, on their reasonable and sustainable use, on the favourable state of the environment being a key factor in ensuring the well-being of people and sustainable development of a country. In such context, environmental law becomes especially relevant in formatting the stable long-term social structure models. Today the environmental requirements of the Russian law do not only make a direct or indirect influence on the rights and obligations of a person, but also determine them in the full variety of their relationships, including economic and social ones.

In its turn, the outcomes of economic growth produce the material values needed for tackling environmental problems, improving natural life conditions, practicing rational and sustainable use of natural wealth. Under such conditions, the continuous and complementary links between the economy and the ecology serving as a guarantee of progressive social development become especially evident. Such objective links predetermine the need for a well-coordinated development of all branches of law based on generally recognized general principles that equally incorporate public interests in economic development and conservation of nature.

Today, the environmental law of Russia is actively searching for a fundamental approach to coordinating the legal regulation of social, economic and ecological relationships in their integrity. One of such approaches is associated with enactment of political strategic documents, where the environmental problems are addressed not in isolation, but within the context of and in interconnection with the goals of socio-economic development. Such an approach corresponds to the basic position expressed at the international level. According to the World Charter for Nature (item 7) "in the planning and implementation of social and economic development activities, due account shall be taken of the fact that the conservation of nature is an integral part of those activities".

By now, many of such acts have already been adopted or approved by various governmental bodies. They comprise quite a number of environment-related policies interconnected with economic and social ones, such as the Ecological Doctrine of the RF, Fundamentals of State Policy in the Area of Ecological Development for the Period till 2030, Strategy of Ecological Security for the Period till 2025, Climate Doctrine of the RF, Water Strategy of the RF for the Period till 2020. In their legal form, these acts are from presidential decrees, governmental regulations and orders, and stand out with their different validity terms. Due to this diversity of formal characteristics it appears impossible to build a hierarchy of such acts, to determine their correlation within the system of legislative acts, to outline a circle of persons, who are to implement and comply with them. In terms of juridical technics, these documents outline the problem addressed, set the policy objective, set the operative tasks, and list the legal and practical measures to be carried out for their attainment. These texts do not mean to determine any personal rights and obligations, neither they provide an enforcement mechanism. They may not adjudicate in courts.

From the legal nature point of view, the Russian legal science regards the strategic and political acts as equal or similar to the Constitution, and referred to as political and regulatory ones. As per the criteria of their designation, contents and juridical techniques applied in their drafting, and according to the Federal Act "On Strategic Planning", the political and regulatory acts belong to the system of strategic planning documents with a unique correction procedure: unlike adoption of amendments, such correction means any operative modification of the text without changing the validity term. Political rule-making is vested with the 
President or the executive bodies at the federal and regional levels, except for the legislature, the State Duma. This fact creates an unusual interconnection between the legislative and executive bodies, when the former ones, despite their primary role within the branches of public power and independence from executive and judicial power, are practically obliged to adopt the statutes that have to, at least, follow, if not to implement the national policy declared at the executive level.

The Code of Administrative Proceedings dated 3 March 2015 sets the rules for repealing ministerial acts either in full or in part upon the administrative claims of the persons to whom the act has been applied or who believe that the act violates or will violate their rights, freedoms and lawful interests (Article 208). The rule covers both mandatory ministerial acts, such like regulatory orders, decrees and decisions, and also the acts of "regulatory quality" and interpretative nature, adopted in the form of ministerial letters, national standards, or reference books. In the latter case, the legal nature of the acts of "regulatory quality" but not being regulatory documents is not clear; as per the position elaborated by the Constitutional Court of the RF, it is up to the court to decide whether the disputed act does or does not conform to the established criteria. If it is adopted by a regulatory body possessing a legislative mandate, addresses to an unlimited circle of persons, and is deemed to be applied many times, it will be recognized as a mandatory document, not an act of explanatory, informative or interpretative nature. According to the Code of Administrative Proceedings, both regulatory acts and acts of regulatory qualities or containing any legislative interpretations shall be subject to judicial review. Strategic acts do not claim to have such qualities at all, as they are not meant to establish any general mandatory rules, but outline the political priorities and general implementation framework for the relevant executive entities; they do not concern any physical or legal persons, their provisions are not that much informative or interpretative, but rather policy-making. As they may contradict with the citizens' rights, they may provoke a civil suit, but only when a certain governmental regulation is adopted to implement a strategic document. Despite certain rules concerning the adoption of strategic documents, the legislation and judicial practice remain mute about the legal force and review of the documents that combine features of the two abovementioned types of acts, regulatory acts and acts of regulatory nature, officially relegating them to neither.

Regardless of this vague legal nature of strategic documents, they are gaining an ever-growing role in regulating environmental relationship. They also have made an important first step to integrate environmental protection interests into socio-economic development policies.

Approved by the Governmental Order dated 31 August 2002, the Ecological Doctrine of the Russian Federation proclaims that the natural environment should be incorporated into the system of socio-economic relationships as the most valuable component of the national heritage. The strategy of socio-economic development and the state ecological policy should be interconnected, as health, social and environmental well-being of people present an inseparable integrated unity.

A more straightforward approach to integrating ecological, economic and social interests and comprehensive legal regulation is expressed in another strategic document adopted 10 years thereafter, the Fundamentals of the National Policy of Ecological Development for the Period till 2030 (further Ecological Development Policy), approved by the President of the RF on 30 April 2012. It requires the national ecological development policy to be strategically intended to solve the socio-economic tasks that would ensure environment-oriented economic growth. Consequently, it is not socio-economic development as an absolute value expressed in growth indicators, but the socio-economic growth that considers and guarantees the ecological interests of the society to preserve the environment for a longterm perspective that is proclaimed as the political basis for the development of the state. Even though the activities implemented to observe these interests may keep the absolute 
economic growth back at certain stages, they shall remain an irreplaceable deposit to achieve long-term sustainable development of all social institutions.

To a certain extent, the Ecological Development Policy follows the Sustainable Development Concept (Our Common Future) and Sustainable Development Goals approved by the United Nations in 2015, and supports the Ecological Law and the Governance Association concept on promotion of ecological law based on the principle of ecological justice and equality among living people, present and future generations in living nature, to sustain integrity of nature, to develop ecological thinking and practice in human minds, "to subordinate our material expectations and desires to the delicate balance of our planet".

The Concept of Long-Term Socio-Economic Development of the Russian Federation for the Period till 2020 as approved by Governmental Order No. 1662-r dated 8 August 2009 similarly envisages that the economic development itinerary is planned with the environment factors taken into account. It states that an improved system of ecological regulation that meets the priorities of national development till 2020 and the new post-industrial level of social development of Russia shall become an institutional basis for a new ecological policy. The ecological policy shall be aimed at a considerable improvement of the quality of the environment and ecological conditions of human life, creating a balanced environment-oriented model of economic development and ecologically competent industries.

The political declarations mean the ecological development principle has been forming within the environment legal protection system through the official recognition and legal provision. It formed a general basic framework for the entire legal system, being a new legal principle for the national policy as a whole and ecological policy in particular. This principle forwards the law to address the socio-economic tasks intended to ensure the environment-oriented economic growth, preserve the favourable environmental conditions, biological diversity and natural resources to meet the needs of the present of future genera- tions, input into environmental rule of law and ecological security.

The greatest challenge of formulating the ecological development model lies upon the environmental legislation that has been previously based on the dynamically and sustainably developing theory of environmental law, and comprising the legal rules that ensure tackling of environmental problems in the context of economic development. Industries are obliged to comply with ecological standards, including the traditional environment quality requirements and emission standards, practice and introduce the best available techniques. The new restrictions that prohibit the placement of certain industrial facilities within water protective zones adjacent to water bodies (Article 65 of the Water Code of the RF, Article 104 of the Forest Code of the RF), within the forest lands (Article 13 - forest infrastructure facilities, Articles 102-107 - prohibition to locate capital constructions within protected forests), within other valuable lands, force the operators to select environmentally safe areas for their economic activity. According to Article 32 of the Federal Act "On Environmental Protection", environmental impact assessment as a mechanism for adopting environmentally safe governmental decisions concerning the planned economic projects is a mandatory requirement for all legal persons engaged in economic and other activities.

At the same time, the legal principle of ecological development determines new guidelines and priorities for environmental law. Firstly, legal environmental requirements should not impede the economic development. In other words, ecological restrictions, prohibitions and prescriptions should not cut down the gross domestic product, interfere with the well-being of people and their living standards. The Ecological Development Policy points out the priority environmental problems to be solved as soon as possible. They include environment-friendly waste disposal, compensation of environmental damage, mitigation of the environmental consequences of past economic activities, introducing new approaches to environmental standard-setting based on technological standards, protecting natural 
ecological systems, flora and fauna. There are some interesting and rather radical approaches to notice. The environmental standard-setting recommends giving up the "zero risk" concept (it means adjustment of the environment quality standards and emission limitations to prevent environment-related diseases) in favour of laxing the quality and emission requirements to support economic interests. According to the National Ecological Policy, industries should adhere to the technological standards that set the "acceptable risk for the environment and people's health".

Ecological development also implies reforming the pollution charge computation methodology. The Ecological Development Policy suggests to refuse from temporary emission limitations currently allowed in exceptional cases during reconstruction and modernization that would result in a higher pollution charge, and to require every facility to compensate the environmental damage in any case whenever the emission standard is exceeded. The Ecological Development Policy also promotes the ecosystem regulation mechanism, which requires, particularly, preservation of natural ecosystem functions both inside the special protected areas and beyond.

The ecological development principle extends to the regulation of economic activities that traditionally falls within civil and business laws. The Ecological Development Policy provides for creating a legal model of an effective, competitive and environment-oriented economy, a task to be integrated into economic branches of law. The priorities have been set. The priority of legal regulation is awarded to equipping the industries with innovative eco-friendly technologies, and assessing the efficiency of the economy not only through the traditional qualitative and quantitative production parameters, but also through the efficiency of natural resources involved in the process.

Civil and business law also need to be involved into addressing the problem of mitigating the previous environmental damage. The Ecological Development Policy prescribes to explore the previous damage and arrange stepby-step activities to clean the pollution from the past economic activities (sites of stocked environmental damage, abandoned landfills, heavily polluted sites), as well as to develop proper legal mechanisms to involve investors into the reclamation activity. In 2016, a long provision on eliminating stocked environmental damage was included into the Federal Act "On Environmental Protection" (Chapter XIV.1), but unfortunately many details of reclamation process were not addressed. The criteria for recognition of environmental damage as past or stocked were not formulated. As at the past pollution sites left since the Soviet times no liable persons were found, no balanced model for finding liable persons to compensate the expenses was suggested. For the time, the expensive works on identification and registration of the past polluted sites are carried out by the government and most of the expenses are covered by the federal budget.

Even though the documents that may finally bring a reform in environmental law are generally positively accepted, some criticism has been already pronounced.

The critics point at the lack of legislative basis for implementing the Ecological Doctrine, lack of mandatory legal force of the political documents that undermine the idea of strategic planning; they notice the incomplete coverage of ecological security issues in the Strategy of Ecological Security (2017) that misses problems of depletion of natural resources, water and biological resources. Lack of mechanisms for enforcing the political documents and mitigating the possible contradictions between these documents and mandatory laws and regulations undermines the significance of strategic documents. Even though the Ecological Doctrine proclaims the objective to strengthen the role of environmental expert review, the list of activities subject to such review was limited by the Federal Act "On Ecological Expertise", and the mechanism itself, therefore, lost its relevance.

This criticism may be added with the evident fact that there have already been some deviations from the national ecological policy in regulatory acts. If the Ecological Development Policy provides for switching from "the pollution charges for exceeded pollution standards to compensation of environmental dam- 
age", the governmental regulation adopted on 3 March 2017 "On Calculating and Collection of Charges for the Negative Impacts on the Environment", i.e. enacted 5 years after the adoption of the Ecological Development Policy (2012), established the same excessive pollution charge collection system, thus once again legalizing the pollution that breaches the quality standards.

Besides, it should not be ignored that regulation by strategic documents has become an uncontrolled and unpredictable process, when the number of strategic documents is growing and the scope of issues they cover is expanding. Moreover, the logic in this activity is not always evident. For instance, there is a Water Strategy, but no Forest Strategy. There is a Strategy for the Conservation of Rare and Endangered Species for the period till 2030, but no strategy for the protection of wildlife or biological diversity as a whole, even though the protection of biodiversity is proclaimed as one of the objectives by the Policy of Ecological Development.

One may also notice some duplications among strategic environment-related documents. It is hard to understand, why a Strategy of Ecological Security has been adopted as a separate strategic document, if when ecological security issues are covered both by the Ecological Development Policy and the Ecological Doctrine. Besides, the objectives of the latter documents coincide to a great extent. The Ecological Development Policy is intended "to preserve favourable environmental conditions, conserve biological diversity and natural resources for the needs of the present and future generations" and comprises ecological security. The aims of the national Policy of Ecological Security are formulated as "to preserve and restore the natural environment, to maintain the environmental quality on the level needed for favourable life conditions and sustainable development, elimination of past environmental damage caused by economic activities under the conditions of economic growth and climate change". Therefore, the border between the objectives of environmental protection and those of ecological security is hardly visible.

There arise some new questions concerning interpretation and implementation of ecological policy as a separate sector in the national policy. According to the Strategy of Economic Security for the Period till 2030, "excessive limitations in ecological security, growing costs of environmentally friendly production and consumption standards" are viewed among the challenges and threats to economic security. Therefore, the ecological security policy should be implemented with the declared economic and financial challenges in mind as long as both documents are equal in their legal force.

From everything said above it becomes evident that harmonization of strategic documents is an urgent matter. There are two options to suggest. Firstly, in view of the existing law-making practice when national policy objectives are expressly formulated in the respective legislative acts or included therein as separate chapters, it seems reasonable to apply this model to environmental policy. A separate law on the national environmental policy or a chapter on environmental policy within the Federal Act "On Environmental Protection" may proclaim long-term guidelines for the development of environmental, ecological security and nature use-related legal acts through creative codification of the existing political and strategic documents. With this approach, the national environmental policy may finally acquire a fully legal, sustainable and long-term character. A policy formulated in a legislative act will obtain a clear mandatory legal force, outline a circle of persons in charge of its implementation to become a firm basis for enacting further strategic and programmed documents as tools for law implementation.

Such law-making practice is already available. For instance, there is a Federal Act "On Industrial Policy", Federal Act "On Science and National Scientific and Technological Policy". The Federal Act "On Standard-Setting" has Chapter 2 "National Policy in Standard-Setting". Separate chapters on national policies in relevant sectors are also included into the Federal Acts "On Heat Supply", "On Electric Energy Industry" (Chapter "Investment Policy in Electric Energy"), "On Gas Supply" (Chapter "Principles of the National Policy in Gas Supply Sector"). 
Alternatively, it would be less complicated to codify the adopted political and strategic documents through a thorough review and comparison of their provisions, withdrawal of duplicating formulations, and in- clusion cross-references to make a clear link between them. The dilemma of their legal force would still remain unclear, leaving the problem of their relevance to other legislative acts.

\section{References}

Decree of the President of the Russian Federation of April 19, 2017 No. 176 On the Strategy of Ecological Security of the Russian Federation for the period until 2025. Available at: https://www.prlib.ru/en/ node/681511

Decree of the President of the Russian Federation of May 13, 2017 No. 208 On the strategy of economic security of the Russian Federation for the period up to 2030. Available at: http:// www.consultant.ru/cons/cgi/online.cgi? req $=$ doc \&base $=$ LAW $\& n=216629 \&$ fld $=134 \& d s t=100017,0 \& r$ nd $=0.39519425476324144 \# 05848230117088864$

Federal Law No. 35-FZ of March 26, 2003 On Electric Energy Industry. Available at: http://www. consultant.ru/cons/cgi/online.cgi?req $=$ doc $\&$ base $=$ LAW $\& n=302970 \&$ fld $=134 \& \mathrm{dst}=1000000001,0 \& \mathrm{r}$ nd $=0.5882340793036087 \# 013972971432458858$

Federal Law No. 69-FZ of March 31, 1999 On gas supply in the Russian Federation. Available at: http://www.consultant.ru/cons/cgi/online.cgi?req=doc\&base $=$ LAW\&n=304416\&fld $=134 \& d s t=1000000001$ , $0 \& \mathrm{rnd}=0.47770273787524764 \# 028968107234158125$

Federal Law No. 162-FZ of June 29, 2015 On Standard Setting. Available at: http://www.consultant.ru/cons/cgi/online.cgi? $r e q=$ doc $\&$ base $=$ LAW $\& \mathrm{n}=201438 \&$ fld $=134 \& \mathrm{dst}=1000000001,0 \& \mathrm{r}$ nd $=0.9579658576251433 \# 0041171902360531476$

Federal Law No. 172-FZ of June 28, 2014 On Strategic Planning. Available at: http://www.consultant. ru/document/cons_doc_LAW_164841/

Federal Law No. 190-FZ of July 27, 2010 On Heat Supply. Available at: http://www.consultant.ru/cons/cgi/online.cgi? $\mathrm{req}=$ doc $\&$ base $=$ LAW $\& \mathrm{n}=302970 \& \mathrm{fld}=134 \& \mathrm{dst}=1000000001,0 \& \mathrm{r}$ nd $=0.5882340793036087 \# 013972971432458858$

Federal Law No. 488-FZ of December 31, 2014 On Industrial policy in the Russian Federation. Available at: http://www.consultant.ru/cons/cgi/online.cgi?req=doc\&base $=$ LAW\&n=301208\&fld=134\&dst=100 0000001,0\&rnd $=0.98686146998641 \# 07414445856952678$

Gizzapulin, R.H. (2016). Legal regulation of implementing the Fundamentals of the National Policy of Ecological Development. In Ecological Law, 5, 3-6.

Khabrieva, T.Ia., Lazarev, V.V., Gabov, A.V. (2017). The Judicial Practice in Contemporary Russia. Moscow, Norma, $432 \mathrm{p}$.

Liability for Environmental Damage in Eastern Europe, Caucasus and Central Asia: Implementation of Good International Practices. Available at: http://www.oecd.org/env/outreach/50244626.pdf

Ruchkina, G.F., Merkushova, O.V. (2017). Legal Approaches to Tackling Current Problems of Ecological Crisis. In International Public and Private Law, 4, 28-32.

Rusin, S.N. (2017). Ecological Security in the System if National Security of the Russian Federation. In Administrative Law and Procedures, 5, 25-28.

Zhavoronkova, N.G., Shpakovsky, Iu.G. (2017). Legal Regulation of Environmental Security under Conditions of Economic Integration. Moscow, Prospect Publishers, $160 \mathrm{p}$.

Zhavoronkova, N.G., Agafonov, V.B. Trends and Perspectives in Improving the State Policy of Ecological Development. In Actual Problems of the Russian Law, 7, 162-173. 


\title{
Стратегические инструменты регулирования в экологическом праве России
}

\author{
И.О. Краснова, В.Н. Власенко \\ Российский государственный университет правосудия \\ Российская Федерачия, Москва
}

\begin{abstract}
Аннотация. Экологическое право России сталкивается с появлением новых видов правовых актов. Несмотря на неопределенную юридическую природу стратегических документов, они начинают играть все большую роль в регулировании экологических отношений, хотя регулирование стратегическими документами приобрело характер неконтролируемого и непредсказуемого процесса. В этой статье рассматриваются стратегические и политические документы, касающиеся защиты окружающей среды, экологической безопасности и природопользования. Это указывает на необходимость найти свое место в системе экологических правовых актов с целью установить четкую иерархию в системе, повысить эффективность законов и создать работающий механизм реализации. Предложены две альтернативы - принять отдельный законодательный акт о национальной экологической политике или включить отдельную главу в Федеральный закон «Об охране окружающей среды» либо, в качестве альтернативы, выполнить кодификацию принятых стратегических инструментов.
\end{abstract}

Ключевые слова: стратегические документы, экологическое право, использование природных ресурсов, экологическая доктрина, экологическая безопасность, национальная политика экологического развития, плата за загрязнение, экономическая безопасность.

Научная специальность: 12.00.00 - юридические науки. 